$\begin{aligned} \text { LA-UR-97- } & \\ \text { Title: } & \begin{array}{l}\text { INTEGRATED SYSTEMS ANALYSIS } \\ \text { APPLIED TO ENVIRONMENTAL } \\ \text { REMEDIATION }\end{array}\end{aligned}$

Author:

Gary Thayer, TSA 4

R. Wayne Hardie, TSA-4

Robert Catherwood, EES-15

RECEIVED

Everett $P$. Springer, EES-15

FEB 021998

OSTI

Submitted to:

DOE Office of Scientific and Technical Information (OSTI)
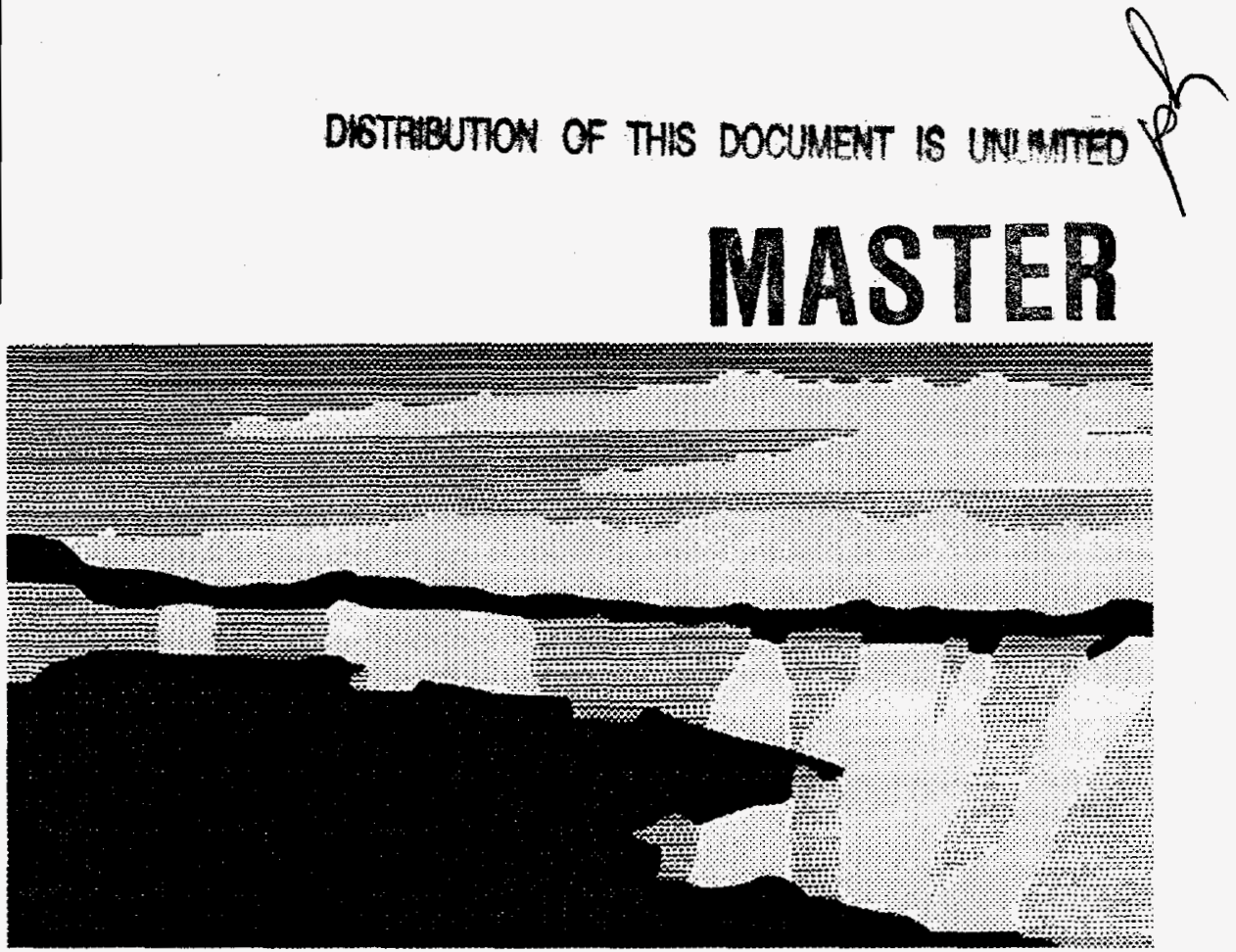

NATIONAL LABORATORY

Los Alamos National Laboratory, an affirmative action/equal opportunity employer, is operated by the University of California for the U.S. Department of Energy under contract W-7405-ENG-36. By acceptance of this article, the publisher recognizes that the U.S. Government retains a nonexclusive, royalty-free license to publish or reproduce the published form of this contribution, or to allow others to do so, for U.S. Government purposes. The Los Alamos National Laboratory requests that the publisher identify this article as work performed under the auspices of the U.S. Department of Energy. Los Alamos National Laboratory strongly supports academic freedom and a researcher's right to publish; therefore, the Laboratory as an institution does not endorse the viewpoint of a publication or guarantee its technical correctness. 


\section{DISCLAIMER}

This report was prepared as an account of work sponsored by an agency of the United States Government. Neither the United States Government nor any agency thereof, nor any of their employees, makes any warranty, express or implied, or assumes any legal liability or responsibility for the accuracy, completeness, or usefulness of any information, apparatus, product, or process disclosed, or represents that its use would not infringe privately owned rights. Reference herein to any specific commercial product, process, or service by trade name, trademark, manufacturer, or otherwise does not necessarily constitute or imply its endorsement, recommendation, or favoring by the United States Government or any agency thereof. The views and opinions of authors expressed herein do not necessarily state or reflect those of the United States Government or any agency thereof. 


\section{DISCLAIMER}

Portions of this document may be illegible electronic image products. Images are produced from the best available original document. 


\title{
Integrated Systems Analysis Applied to Environmental Remediation
}

\author{
Gary R. Thayer \\ R. W. Hardie* \\ Robert Catherwood \\ Everett P. Springer.
}

\begin{abstract}
At the request of the Congressional Task Force on the Salton Sea and the Salton Sea Authority, we examined various technologies that have been proposed to reduce the decline in the Salton Sea. The primary focus of the technologies was to reduce the salinity of the Salton Sea, with secondary objectives of maintaining the present shoreline and to have a minimum cost. We found that two technologies, pump-out and diking, could provide the required salinity reduction. The pump-out option would result in a smaller Sea while to diking option would create a high salinity impoundment area in the Sea. The costs for the two options were similar. Desalination and pump-in; pump-out options were rejected because of high costs and because they did not provide a sufficient reduction in the salinity of the Salton Sea. The end product of the project was testimony before the Subcommittee on Water and Power, U. S. House of Representatives Committee on Resources, given October 3, 1997.
\end{abstract}

\section{Background and Research Objectives}

The Salton Sea is a isolated inland lake created in 1905 from a accidental diversion of the Colorado River. The lake has no outlet and has been maintained since its creation by run-off water from irrigation in the Imperial Valley. Over the years the Salton Sea has supported a large fish population which, in turn, has supported recreational fishing and large bird populations. The Salton Sea has replaced the Los Angeles area as a stopping point for migrating birds in the Pacific Flyway and now boasts one of the largest concentrations of migrating sea birds in the west.

Since 1905 the salinity of the Salton Sea has gradually increased as the incoming irrigation water is evaporated until today the salinity 20 to $25 \%$ greater than that of the ocean and is approaching levels that will be unable to support fish life. In addition, the past few years there has been a large bird die -offs in the Salton Sea caused by birds eating diseased fish and possibly due to the accumulation of hazardous materials in sediments. 
A Congressional Task Force and an organization (The Salton Sea Authority) have been created to examine methods to reverse the decline of the Salton Sea. Los Alamos has been requested by the Congressional Task force to provide technical assistance to the Task Force and the Salton Sea Authority in examining possible solutions to the problems existing at the Salton Sea. This LDRD supported the analyses requested by those organizations

\section{Importance to LANL's Science and Technology Base and National R\&D Needs}

The project was in response to a request to provide technical assistance on an environmental problem that was facing the Salton Sea. Because of the large bird die-offs and increasing environmental problems at the Salton Sea, congressional and national attention has focused on ways to alleviate the problems. Because of this attention, studies on the Salton Sea and its environment are being undertaken. This project allows the Laboratory to provide technical assistance by using the results of these studies in a Systems Analysis approach to provide the information decision makers require. The analysis of the this problem requires a systems and Integrated Environmental Science approach. The Laboratory's core competencies in Earth and Environmental Systems and Analysis and Assessments, especially in Systems Analysis and Cost/Benefit Tradeoff Analysis, are required to address the problems.

\section{Scientific Approach and Accomplishments}

The primary activities supported by this LDRD were:

1. To analyze a Pump-In; Pump-Out scenario for remediating the Salton Sea

2. To analyze diking scenarios for remediating the Salton Sea

3. To provide comments on desalination plant proposals

4. To provide testimony at a congressional hearing on the Salton Sea.

A brief report on each of these activities follows.

\section{Analyze a Pump-In; Pump-Out Scenario}

We were requested to analyze a proposed scenario where ocean water from the Sea of Cortez would be pumped into the Salton Sea and then water would be pumped from the Salton Sea to a dry lake bed at Laguna Salada in Mexico or alternatively all the way to the Sea of Cortez. We examined a base case plus two alternatives for this scenario and determined that capital costs would be 1.3 to 1.6 billion dollars and operating costs would be 26 to 40 million dollars per year. Also, we determined that this scenario would not 
reduce the salinity levels of the Salton Sea to that of ocean water, the goal of the Salton Sea Authority.

We also provided an analysis of the financing scheme proposed to finance this scenario and found that because of the timing of the income and the expenses that the financing scheme was not viable. The proposed method of financing the project was to sell excess water to the City of San Diego. This method would result in most of the income being accrued in the end years of the project while a majority of the expenses would occur in the early years of the project. Because of the timing of the income and expenses, the expected income would not be sufficient to cover the project expenses and interest.

\section{Analyze Diking Scenarios}

We provided an analysis of a scenario where a diked impoundment area would be created in the Salton Sea. Water from the main part of the Sea would be introduced into the impoundment area and allowed to evaporate, thus providing an outlet for the main part of the Sea. We determined that this was capable of reducing the salinity of the main part of the sea to ocean water level and could maintain the present shore line of the lake. The cost estimates provided for the scenario were correct as far as we could determine.

The main point that we stressed when this was presented to the Congressional Task Force was that a systems analysis is required for the Salton Sea Problems. All aspects of the Salton Sea, the proposed fixes, the environmental consequences of the fixes, and the final state of the sea must be included in the analysis. We presented a specific approach for this systems analysis.

\section{Comments on Desalination Plant Proposals}

The Metropolitan Water District (Los Angeles) and US Filter have presented proposals to the Salton Sea Authority to construct desalination plants to remove salt from the inflow to the Salton Sea and to finance the plants by selling the desalinated water. We were requested to comment on these proposals.

Our analysis of the proposals concluded that the they did not contribute anything to solving the problems at the Salton Sea. In fact, because they would divert water that is presently going into the Salton Sea, they would speed up and exacerbate the problems of the increase in salinity of the Sea and the shrinkage of the Sea. The desalination plants would produce 
very expensive fresh water which possibly could be economical for home use, but would not be economically viable for remediating the Salton Sea.

\section{Testimony for a Congressional Hearing on the Salton Sea}

We were requested to provide testimony at a Congressional Hearing on the Salton Sea, to be held on October 3, 1997. We prepared a statement to be presented at that hearing (LAUR ????). In that statement we examined four aspects of the Salton Sea problem;

- industrial and municipal waste

- selenium concentrations

- high salinity, and

- variable water levels.

We concluded that the problems concerned with industrial and municipal waste were being addressed and the situation was improving. If the planned construction of the waste treatment plants was completed, the problem with the industrial and municipal wastes entering the Salton Sea would be reduced to a point where they would not constitute a problem.

Selenium concentrations in and around the Salton Sea present a more complex problem. Elevated levels ( 30 to $80 \%$ of the EPA standard for drinking water) of selenium have been measured in the inflow waters to the Salton Sea. However, the selenium concentration in the Sea is less than $10 \%$ of the EPA drinking water standard. Because of the experience at the Kesterson Wildlife Refuge with selenium poisoning, there is considerable concern about whether selenium poisoning is contributing to the present problems or will contribute to future problems in the Salton Sea. Our conclusion was that the present selenium concentrations do not appear to constitute a problem, but that further study is warranted, especially examining the effects of the food chain on concentrating the selenium. Also, the contributions of the present selenium levels to the stress experienced and subsequent die offs of the fish and birds in the Sea need to be studied.

We concluded that there were two viable solutions to the problems of high salinity and variable water levels in the Salton Sea, diking and pumping out water from the Salton Sea. The diking option would provide the ability to maintain the present shore line and reduce the salinity of the main part of the Sea at the expense of creating an impoundment area containing high salinity brine. This impoundment area would not be able to support fish life and eventually would fill with precipitated salt. Eventually this salt would need to be removed, most probably by pumping out the brine. The salinity of the Salton Sea could 
also be reduced by pumping out water from the Sea. This would result in a smaller sea and would change the present shore line. The costs for the two options were comparable.

* Principal Investigator, e-mail: hardie@lanl.gov 


\section{Publications}

1. Hardie, R W. "Evaluation of Options for Remediation of the Salton Sea" Testimony given before the Subcommittee on Water and Power, U.S. House of Representatives Committee on Resources, October 3, 1977, LAUR ??????, Los Alamos National Laboratory, Los Alamos, NM. (Oct. 1997)). 